\title{
AC 2007-1883: FACULTY SCHOLARSHIP AND TECHNICAL CURRENCY: 2007 STATUS REPORT ON A NATIONAL SURVEY OF ENGINEERING TECHNOLOGY FACULTY
}

\section{Ahmed Khan, DeVry University}

Dr. Ahmed S. Khan is a senior Professor in the EET dept. at DeVry University, Addison, Illinois. He received his M.Sc (applied physics) from University of Karachi, an MSEE from Michigan Technological University, an MBA from Keller Graduate School of Management., and his Ph.D. from Colorado State University. His research interests are in the areas of Fiber Optic Communications, Faculty Development, Outcomes Assessment, and Application of Telecommunications Technologies in Distance Education. He teaches Wireless Engineering, Network Engineering, Fiber Optic Communications, Technology and Society, and Project Management. He also advises students on their senior design projects. He is author of "The Telecommunications Fact Book, 2E" and co-author of "Technology and Society: Crossroads to the 21st Century," "Technology and Society: A Bridge to the 21st Century," and "Technology and Society: Issues for the 21st Century and Beyond." He is a member of ASEE, and a senior member of IEEE.

\section{Amin Karim, DeVry University}

Amin Karim is the Director of Technology Programs at DeVry University. In this capacity, he is responsible for leading DeVry's undergraduate and graduate programs in engineering technology, information systems, telecommunications, and biomedical programs. Before joining DeVry in 1991, he has worked in industry, and as a faculty and as a dean of engineering technology. 


\title{
Faculty Scholarship and Technical Currency: 2007 Status Report on a National Survey of Engineering Technology Faculty
}

\begin{abstract}
The accomplishments of the 20th century are revolutionizing science and technology in the $21^{\text {st }}$ century. The rate and pace of technological advancements is following an exponential growth. In the last decade the global society has experienced an expansion of knowledge-based in science, engineering, medicine, and technology of unparallel magnitude and proportions. The time to remake the world is becoming shorter with every new technological revolution. For industrial revolution it took two centuries to remake the world, for electronics it took seven decades. In the $21^{\text {st }}$ century, with the convergence of multiple disciplines of science and technology it may take less than a decade to remake the world.
\end{abstract}

This convergence of multiple-disciplines has put new demands on educators as well on students. As technology leapfrogs and new technological domains evolve, it becomes increasingly important for faculty to keep current with the new and emerging technologies. The global market place requires students to possess an up-to-date technological knowledge-base and complex communications-skill set. In this regard faculty professional development activities and technical currency play an important role in promoting student learning and success.

This paper presents the findings of a national faculty survey conducted through the ETD listserve ((http:etidweb.tamu.edu/listserv.php) which presently has a membership of more than 3,700 faculty members and professionals belonging to more than 800 institutions in 30 countries and all 50 states of the United States. The intent of the survey is to gauge the status of professional development activities vis-à-vis faculty technical currency at personal, departmental and institutional levels in the domains of engineering technology. The paper also compares the current status of faculty scholarship vis-à-vis faculty technical currency to results obtained through earlier studies (2003). 


\section{Introduction}

The exponential rate of technological advances and the convergence of scientific knowledge are remaking the world. As the time to remake the world becomes shorter with every new technological revolution, a new paradigm is required in the domains of teaching and learning. Teaching in today's world requires new approaches to instruction. The profound and pervasive changes occurring in education are placing new demands on educators. Educators are expected to be technically current and learn the mechanics of teaching/learning in order to become effective teachers and to narrow the academiaindustry gap that exits in the curricula.

Accreditation bodies such as the Accreditation Board for Engineering and Technology (ABET) place high emphasis on the technical currency of faculty and require institutions to provide opportunities for faculty to keep abreast of the pace of technological advances. ABET's 2006-2007 criteria for accrediting engineering technology programs state:

Overall competence of the faculty will be evaluated through such factors as formal education, balance of academic experience and professional practice, industrial experience, professional certification, teaching experience, teaching effectiveness, technical currency, scholarly activity, professional society participation, communication skills, extracurricular support for student activities, and similar attributes appropriate to the program objectives. Individual faculty members must have educational backgrounds, industrial experience, professional practice, communication skills, and technologically current knowledge that support the field of instruction and program objectives. Collectively, the faculty must be capable of providing students an appropriate breadth of perspective and effective instruction in the use of modern technical and non-technical methodologies in careers appropriate to the program objectives. The program must have an effective professional development plan for its faculty. The number of faculty members must be sufficient to provide program continuity, proper frequency of course offerings, appropriate levels of student-faculty interaction, and effective student advising and counseling. Each program must have effective leadership through a full-time faculty member with defined leadership responsibilities for the program. The program faculty must have sufficient responsibility and authority to define, revise, implement, and achieve program objectives (ABET, 2007, p.7). ${ }^{1}$

The nature, demands, and vocabulary of scholarship are also evolving. Ernest Boyer, in his 1990 Scholarship Reconsidered: Priorities of the Professoriate, suggested four interrelated dimensions of scholarship; discovery, integration, application and teaching (see Table 1$)^{2}$ 
Table 1. Dimensions of Scholarship according to Ernest Boyer (1990) ${ }^{2}$.

\begin{tabular}{|c|c|}
\hline Scholarship domain & Description \\
\hline The Scholarship of Discovery & $\begin{array}{l}\text { - Research is the central ingredient to } \\
\text { intellectual environment } \\
\text { - The process of discovery }\end{array}$ \\
\hline The Scholarship of Integration & $\begin{array}{l}\text { - The process of making connections } \\
\text { within and across disciplines } \\
\text { - The process is related to discovery and } \\
\text { convergence of disciplines. }\end{array}$ \\
\hline The Scholarship of Application & $\begin{array}{l}\text { - The process of transforming discovered } \\
\text { knowledge into specific applications. } \\
\text { - Application of theory into practice } \\
\text { Ernest Boyer: "the application of } \\
\text { knowledge moves toward } \\
\text { engagement as the scholar asks, } \\
\text { 'How can knowledge be responsibly } \\
\text { applied to consequential problems? } \\
\text { How can it be helpful to individuals } \\
\text { as well as institutions?' And further, } \\
\text { 'Can social problems themselves } \\
\text { define an agenda for scholarly } \\
\text { investigation?'" }\end{array}$ \\
\hline The Scholarship of Teaching & $\begin{array}{l}\text { Ernest Boyer: "The work of the } \\
\text { professor becomes consequential } \\
\text { only as it is understood by others. . } \\
\text { When defined as scholarship } \\
\text { teaching both educates and entices } \\
\text { future scholars. Indeed, as Aristotle } \\
\text { said, 'Teaching is the highest form } \\
\text { of understanding."' }\end{array}$ \\
\hline
\end{tabular}


The swift pace of technological change is transforming the global economy into a knowledge-based economy, in which organizations are no longer valued on the basis on their physical assets but rather on the knowledge-base of their employees. And in this new knowledge-based economy the wealth of a nation is determined by its intellectual capital.

In his book The Digital Economy: Promise and Peril in the Age of Networked Intelligence, Tapscott proposes a dozen themes for the new economy. The first is knowledge. About the requirements of digital economy and faculty practices, he makes the following observations ${ }^{3}$ :

The digital economy requires a far-reaching rethinking of education and, more broadly, learning and the relationship between working, learning, and daily life as consumer. (p.197)

With tenured professors, teachers threatened by technology, less competition, and teaching traditions dating back centuries, many educational institutions have become mired in the past. (p.201)

The concepts of faculty development deals with helping faculty members improve their competence as teachers and scholars ${ }^{4}$. Furthermore, improving faculty competence is a part of improving overall instructional quality. The efforts to increase instructional quality depend on faculty development (focus on faculty), instructional development (focus on student, course and curriculum), and organizational development (focus on structure and process). ${ }^{5}$

Faculty in purely teaching institutions (non-research environments), especially those teaching in technology-based and career-oriented programs, generally lag behind the pace of technological change in terms of their professional development activities due to their non-association with research activities. They face two major challenges: how to incorporate and teach new applications of new technologies in the curriculums they teach and how to maintain their professional currency. ${ }^{6}$

Therefore, in summary, the rapid pace of technological change mandates that faculty remain current in their technical areas of specialization as technology leapfrogs and new domains of technology evolve, and thus they need to become reflective practitioners.

For this article, it was the intent of authors to survey faculty teaching in the engineering technology domain to determine the state of professional development and processes that are used to maintain technical currency and compare the results with the study conducted in 2003. 


\section{Data Collection Procedure}

To gauge the status of professional development activities vis-à-vis faculty technical currency at personal, departmental and institutional levels in the domains of engineering technology, the faculty survey was conducted through the ETD listserv (http:etidweb.tamu.edu/listserv.php) which presently (as of January 2007) has a membership of more than 3700 faculty members and professionals belonging to more than 800 institutions in 30 countries and all 50 states of the United States. The participants were asked to submit their responses anonymously. Appendix A exhibits the survey instrument used for data collection.

\section{Results/Findings}

Table 2 summarizes the frequency and percentage of responses (2003 \& 2007) indicating faculty perceptions about the various aspects of technical currency, its relationship to student learning/success, and the impact of TAC of ABET's TC2k accreditation criteria on the revision of institutional policies to promote faculty development activities and on allocation of financial resources for faculty developmental activities.

Table 2. Results for Survey Questions 1-10 (Technical Currency Issues)

\begin{tabular}{|c|c|c|c|c|c|c|c|c|}
\hline \multicolumn{2}{|l|}{$\begin{array}{l}2007(\mathrm{~N}=127) \\
2003(\mathrm{~N}=226)\end{array}$} & SD & $\mathrm{D}$ & MD & $\mathrm{N}$ & MA & A & SA \\
\hline \multicolumn{2}{|c|}{$\begin{array}{l}\mathrm{F}=\text { Frequency } \\
\%=\text { Percentage } \\
(\% \geq 10 \text { is underlined })\end{array}$} & $\mathrm{F}(\%)$ & $\mathrm{F}(\%)$ & $\mathrm{F}(\%)$ & $\mathrm{F}(\%)$ & $\mathrm{F}(\%)$ & $\mathrm{F}(\%)$ & $\mathrm{F}(\%)$ \\
\hline \multirow{2}{*}{$\begin{array}{l}\text { 1. Because of the } \\
\text { application orientation } \\
\text { of engineering } \\
\text { technology programs, } \\
\text { technical currency of } \\
\text { faculty is essential to } \\
\text { make student learning } \\
\text { more relevant. }\end{array}$} & 2007 & - & - & $2(1.57)$ & $3(2.36)$ & $5(3.9)$ & $29(\underline{22.8)}$ & $88(69.5)$ \\
\hline & 2003 & $1(0.4)$ & $3(1.3)$ & $1(0.4)$ & $O(0)$ & $6(2.7)$ & $78(\underline{34.5})$ & $137(\underline{60.6})$ \\
\hline \multirow{2}{*}{$\begin{array}{l}\text { 2. I believe that there } \\
\text { is a strong relationship } \\
\text { between the technical } \\
\text { currency of the faculty } \\
\text { member and student } \\
\text { learning/success. }\end{array}$} & 2007 & $2(1.57)$ & $3(2.4)$ & $3(2.4)$ & $4(3.14)$ & $4(3.14)$ & $30(23.62)$ & $81(\underline{63.8)}$ \\
\hline & 2003 & $3(1.3)$ & $5(2.2)$ & $10(4.4)$ & $9(4.0)$ & $34(\underline{15.0})$ & $89(\underline{39.4)}$ & $76(\underline{33.6})$ \\
\hline \multirow{2}{*}{$\begin{array}{l}\text { 3. My institution } \\
\text { supports and } \\
\text { encourages faculty } \\
\text { members to maintain } \\
\text { technical currency. }\end{array}$} & 2007 & $7(5.1)$ & $12(9.4)$ & $20(15.7)$ & $27(21.2)$ & $25(\underline{19.7)}$ & $22(17.2)$ & $14(11)$ \\
\hline & 2003 & $6(2.7)$ & $17(7.5)$ & $14(6.2)$ & $20(8.8)$ & $63(27.9)$ & $76(33.6)$ & $30(13.3)$ \\
\hline \multirow{2}{*}{$\begin{array}{l}\text { 4. My chairperson } \\
\text { supports and helps me } \\
\text { plan professional } \\
\text { development activities } \\
\text { to maintain technical } \\
\text { rre currency. }\end{array}$} & 2007 & $20(15.7)$ & $25(\underline{19.7)}$ & $12(9.4)$ & $21(\underline{16.5)}$ & $15(11.8)$ & $18(14.1)$ & $16(12.6)$ \\
\hline & 2003 & $14(6.2)$ & $21(9.3)$ & $18(8.0)$ & $38(16.8)$ & $40(17.7)$ & $63(27.9)$ & $32(14.2)$ \\
\hline
\end{tabular}




\begin{tabular}{|c|c|c|c|c|c|c|c|c|}
\hline \multirow{2}{*}{$\begin{array}{l}\text { 5. I believe that I have } \\
\text { maintained technical } \\
\text { currency during the } \\
\text { past } 5 \text { years, enabling } \\
\text { me to teach courses } \\
\text { effectively. }\end{array}$} & 2007 & $1(0.7)$ & $3(2.4)$ & $17(13.4)$ & $12(9.4)$ & $11(\underline{8.7})$ & $35(27.5)$ & $48(37.7)$ \\
\hline & 2003 & $4(1.8)$ & $8(3.5)$ & $8(3.5)$ & $8(3.5)$ & $53(23.5)$ & $81(\underline{35.8})$ & $64(28.3)$ \\
\hline \multirow{2}{*}{$\begin{array}{l}\text { 6. My institution has } \\
\text { allocated sufficient } \\
\text { funds for the } \\
\text { professional } \\
\text { development activities } \\
\text { of faculty during the } \\
\text { past } 5 \text { years. }\end{array}$} & 2007 & $36(28.2)$ & $27(\underline{21.2})$ & $21(\underline{16.5})$ & $11(8.7)$ & $11(8.7)$ & $10(7.8)$ & $11(8.7)$ \\
\hline & 2003 & $43(19.0)$ & $25(11.1)$ & $29(\underline{12.8})$ & $30(13.3)$ & $52(23.0)$ & $34(\underline{15.0})$ & $13(5.8)$ \\
\hline \multirow{2}{*}{$\begin{array}{l}\text { 7. There is an urgent } \\
\text { need in my } \\
\text { department/program to } \\
\text { improve existing } \\
\text { policies in order to } \\
\text { allow faculty to } \\
\text { enhance their technical } \\
\text { currency. }\end{array}$} & 2007 & $4(3.1)$ & $11(8.7)$ & $20(\underline{15.8})$ & $16(12.5)$ & $25(19.6)$ & $23(\underline{18.1})$ & $28(\underline{22})$ \\
\hline & 2003 & $7(3.1)$ & $34(\underline{15.0})$ & $16(7.1)$ & $37(\underline{16.4})$ & $47(\underline{20.8})$ & $45(\underline{19.9})$ & $40(\underline{17.7})$ \\
\hline \multirow{2}{*}{$\begin{array}{l}\text { 8. There is an urgent } \\
\text { need in my } \\
\text { department/program to } \\
\text { increase funding for } \\
\text { faculty development } \\
\text { activities. }\end{array}$} & 2007 & $7(5.1)$ & $8(6.3)$ & $7(5.1)$ & $16(\underline{12.6})$ & $17(\underline{13.4})$ & $48(\underline{37.8})$ & $24(\underline{18.9})$ \\
\hline & 2003 & $3(1.3)$ & $22(9.7)$ & $17(7.5)$ & $29(\underline{12.8})$ & $38(16.8)$ & $60(\underline{26.5})$ & $57(25.2)$ \\
\hline \multirow{2}{*}{$\begin{array}{l}\text { 9. ABET's new TC2K } \\
\text { accreditation criteria } \\
\text { will encourage my } \\
\text { institution to revise } \\
\text { policies in order to } \\
\text { promote faculty } \\
\text { development activities } \\
\text { in order to keep faculty } \\
\text { technically current. }\end{array}$} & 2007 & $18(14.2)$ & $12(9.4)$ & $10(7.8)$ & $49(38.6)$ & $14(\underline{11})$ & $15(\underline{11.8})$ & $9(7.1)$ \\
\hline & 2003 & $21(9.3)$ & $22(9.7)$ & $14(6.2)$ & $77(\underline{34.1)}$ & $41(18.1)$ & $46(\underline{20.4)}$ & $5(2.2)$ \\
\hline \multirow{2}{*}{$\begin{array}{l}\text { 10. ABET's new } \\
\text { TC2K accreditation } \\
\text { criteria will encourage } \\
\text { my institution to } \\
\text { allocate adequate } \\
\text { financial resources for } \\
\text { faculty development } \\
\text { activities. }\end{array}$} & 2007 & $12(9.4)$ & $27(\underline{21.6})$ & $8(6.3)$ & $45(\underline{35.4)}$ & $16(\underline{12.6})$ & $12(9.4)$ & $7(5.1)$ \\
\hline & 2003 & $23(10.2)$ & $23(\underline{10.2)}$ & $23(10.2)$ & $84(\underline{37.2})$ & $39(17.3)$ & $28(\underline{12.4)}$ & $6(2.7)$ \\
\hline
\end{tabular}

\section{Technical currency of faculty is essential to make student learning more relevant:} Out of 127 respondents, $22.8 \%$ said they agree (A) while $69.5 \%$ said that they strongly agree (SA) with the notion that because of the application orientation of engineering technology programs, technical currency of faculty is essential to make student learning more relevant, whereas $2.3 \%$ moderately disagree (MD). The level of agreement (97.8\%) for 2007 results is similar to 2003 results $(96.2 \%)$. 
2. Strong relationship between technical currency and student learning: $63.6 \%$ of respondents strongly agree (SA), $23.6 \%$ agree $(\mathrm{A}), 3.1 \%$ moderately agree (MA), $1.5 \%$ strongly disagree (SD), and $2.4 \%$ disagree (D) with the concept that there is a strong relationship between the technical currency of the faculty member and student learning/success. The levels of agreement (90.6\%) for 2007 results are similar to 2003 results $(88 \%)$.

\section{Institutional support/encouragement for faculty to maintain technical currency:} $11 \%$ respondents strongly agree (SA), $17.2 \%$ agree (A), $19.7 \%$ moderately agree that they have institutional support/encouragement to maintain technical currency, while $5.1 \%$ strongly disagree (SD), 9.4\% disagree (D), 1.6 moderately disagree (MD), and $21.2 \%$ expressed no opinion $(\mathrm{N})$. The results reveal that the level of agreement decreased from $74.8 \%$ (2003) to $47.9 \%$ (2007).

\section{Chairperson's support for faculty for professional development} activities/maintenance of technical currency: $12.6 \%$ of respondents strongly agree (SA), $14.1 \%$ agree (A), $11.8 \%$ moderately agree (MA), $15.7 \%$ strongly disagree (SD), $19.7 \%$ disagree (D), and $9.4 \%$ moderately disagree (MD) that their chairperson helps and supports them to plan their professional development activities to maintain technical currency, and $16.5 \%$ expressed no opinion $(\mathrm{N})$. The results indicate that that the level of disagreement increased from $23.5 \%$ (2003) to $44.8 \%$ (2007).

5. Faculty maintained technical currency during past 5 years to teach effectively: $37.7 \%$ participants strongly agree (SA), 27.5\% agree (A), 8.7\% moderately agree with the idea that they have maintained technical currency during the past 5 years to teach courses effectively, while $0.7 \%$ strongly disagree (SD), $2.4 \%$ disagree (D), $13.4 \%$ moderately disagree (MD), and $9.4 \%$ expressed no opinion $(\mathrm{N})$. The results reveal that the level of agreement decreased from $87.6 \%$ (2003) to $73.9 \%$ (2007).

\section{Institution has allocated sufficient funds for professional development during the} past 5 years: Only $8.7 \%$ of respondents strongly agree (SA), 7.8\% agree (A), 8.7\% moderately agree with the statement that the institution has allocated sufficient funds for the professional development activities of faculty during the past 5 years, while $28.2 \%$ strongly disagree (SD), 21.2\% disagree (D), and 16.5\% moderately disagree, and $8.7 \%$ expressed no opinion $(\mathrm{N})$. The results indicate that that the level of disagreement increased from $42.7 \%$ (2003) to $65.9 \%$ (2007).

\section{Urgent need to improve existing departmental polices to allow faculty enhance their} technical currency: $22 \%$ of the faculty members strongly agree (SA), $18 \%$ agree (A), $19.6 \%$ moderately agree (MA) with the suggestion that there is an urgent need at department/program level to improve existing policies in order to allow faculty members to enhance their technical currency, while $3.1 \%$ strongly disagree (SD), $8.7 \%$ disagree (D), $15.8 \%$ moderately disagree (MD), and $12.5 \%$ expressed no opinion (N). The results show that the level of agreement remained almost same for the $2003(58.4 \%)$ and 2007 $(59.2 \%)$ survey. 
8. Urgent need to increase department/program funding for faculty development activities: $18.9 \%$ of respondents strongly agree (SA), $37.8 \%$ agree (A), $13.4 \%$ moderately agree with the statement that there is an urgent need to increase funding at department/program level for faculty development activities, while 5.1\% strongly disagree (SD), 6.3\% disagree (D), and 5.1\% moderately disagree (MD, and $12.6 \%$ expressed no opinion $(\mathrm{N})$. The results reveal that the level of agreement remained almost same for the $2003(68.5 \%)$ and 2007 (70.1\%) survey.

\section{Impact of ABET's TC2K accreditation criteria on revision of institutional policies} for promoting faculty developmental activities to keep faculty technically current: Only $7.1 \%$ of respondents strongly agree (SA), $11.8 \%$ agree (A), $11 \%$ moderately agree (MA) with the idea that ABET's TC2K accreditation criteria will encourage their institutions to revise policies for promoting faculty development activities in order to keep faculty technically current, while $14.2 \%$ strongly disagree (SD), 9.4\% disagree (D), and $7.8 \%$ moderately disagree (MD), and $38.6 \%$ expressed no opinion $(\mathrm{N})$. The results indicate that that the level of disagreement increased from $25.2 \%$ (2003) to $31.4 \%$ (2007).

\section{Impact of ABET's TC2K accreditation criteria on allocation of adequate financial} resources for faculty development activities: Only 5.1\% participants strongly agree (SA), 9.4\% agree (A), $12.6 \%$ moderately agree (MA) with the notion that ABET's TC2K accreditation criteria will encourage their institutions to allocate adequate financial resources for faculty development activities, while 9.4\% strongly disagree (SD), $21.6 \%$ disagree (D), $6.3 \%$ moderately disagree (MD), and $35.4 \%$ expressed no opinion (N). The results reveal that the level of disagreement increased from $30.6 \%$ (2003) to $37.3 \%$ (2007).

11. Modes for maintaining technical currency: Figure 1 shows the frequency distribution of various modes used by respondents to maintain their technical currency. Reading books, magazines and journals; attending conferences/technical workshops/seminars; and keeping up-to-date via the Internet are the most widely used modes for faculty to maintain their technical currency, whereas working as consultants and knowledge/skills transfer from senior faculty/colleges are the least practiced modes.

The results indicate a significant decrease in the participants reported level of attending conferences, workshops, seminars for maintaining technical currency. In 2003, 80\% participants reported that they used this mode to maintain technical currency, whereas in 2007 , only $57 \%$ participants used this mode to maintain technical currency.

The mode of "Keeping up-to-date via Internet" remained the most widely used resource for maintaining technical currency. The participants' use of this mode increased from $73 \%$ (2003) to $80 \%$ (2007). 


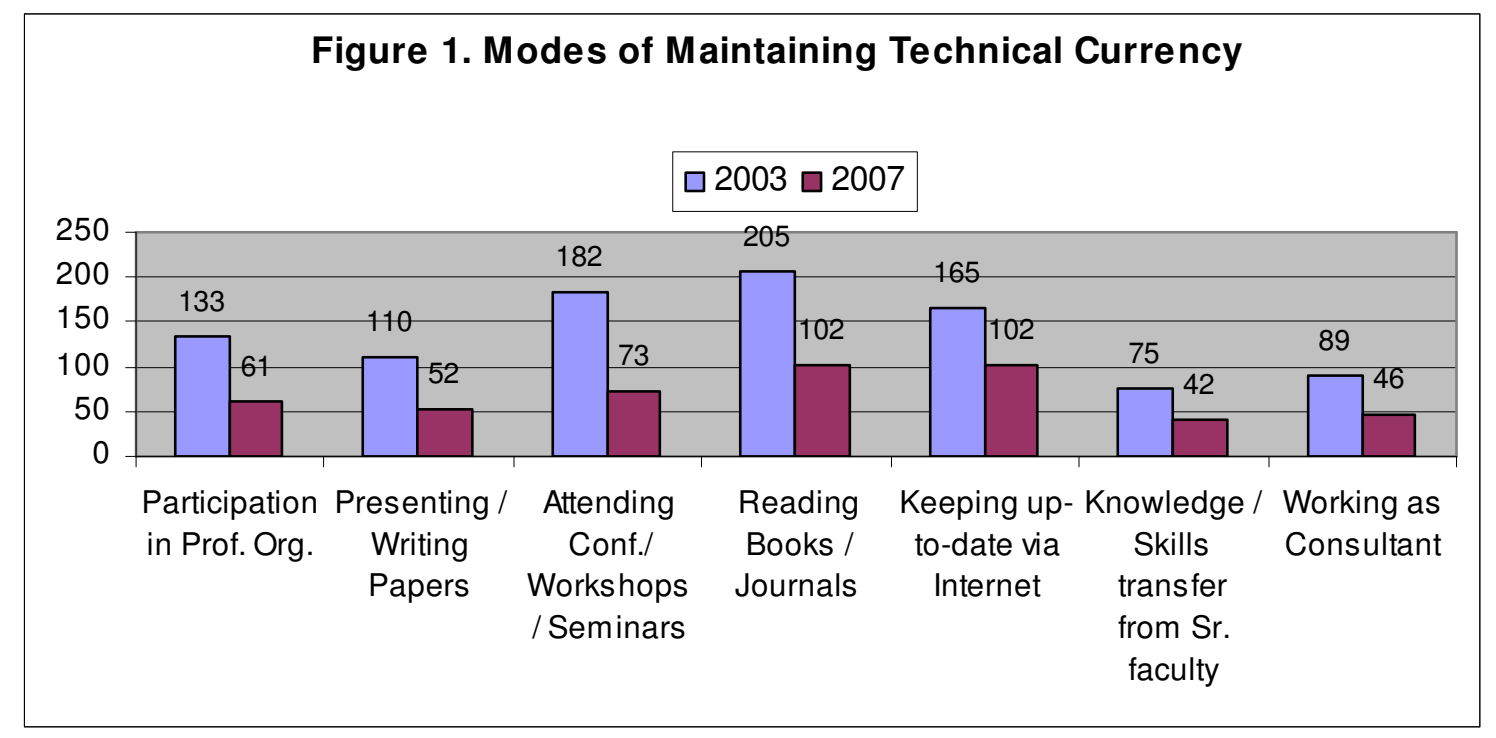

12. Institutional Affiliation: Figure 2 shows the frequency distribution of respondents' institutional affiliations. The

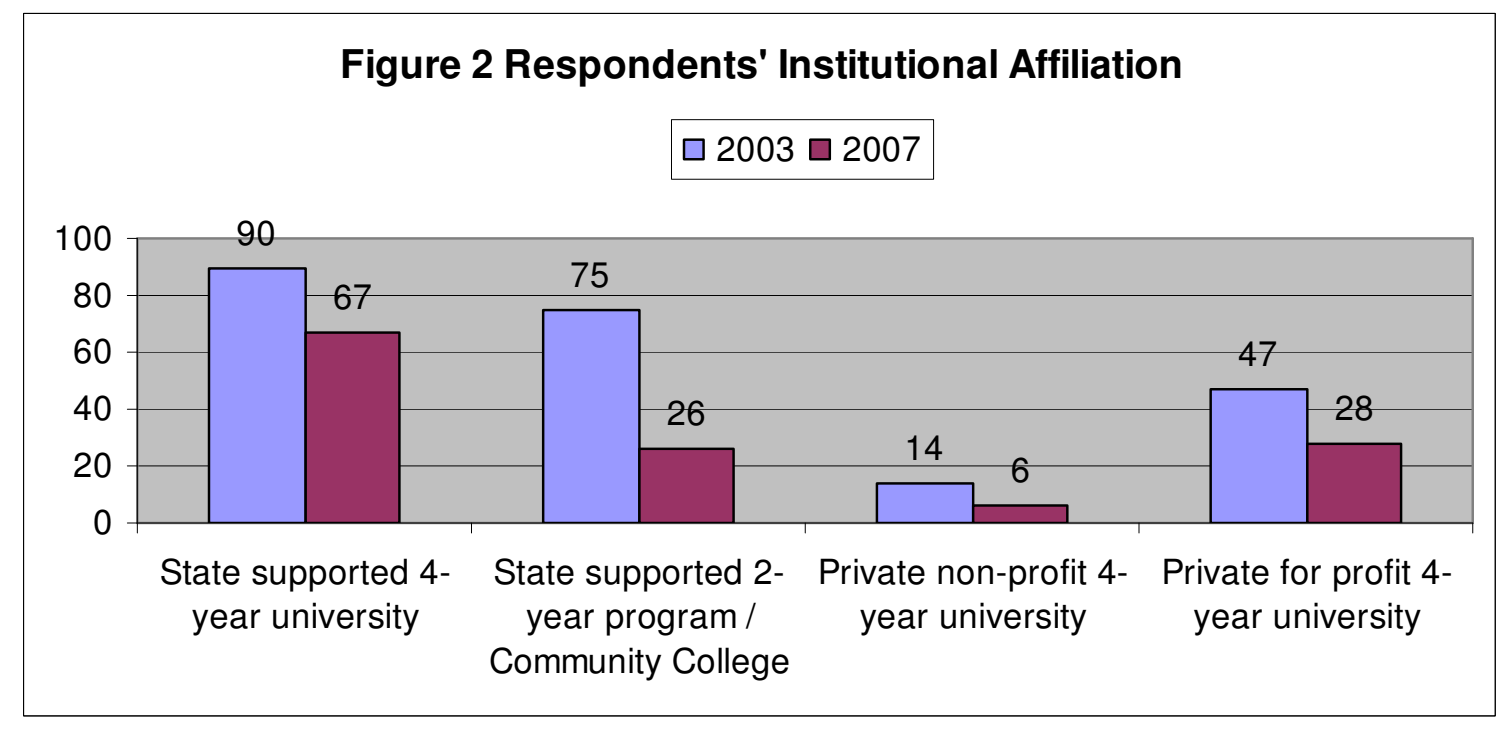

13. Departmental Affiliation: Figure 3 shows the frequency distribution of respondents' professional areas. 


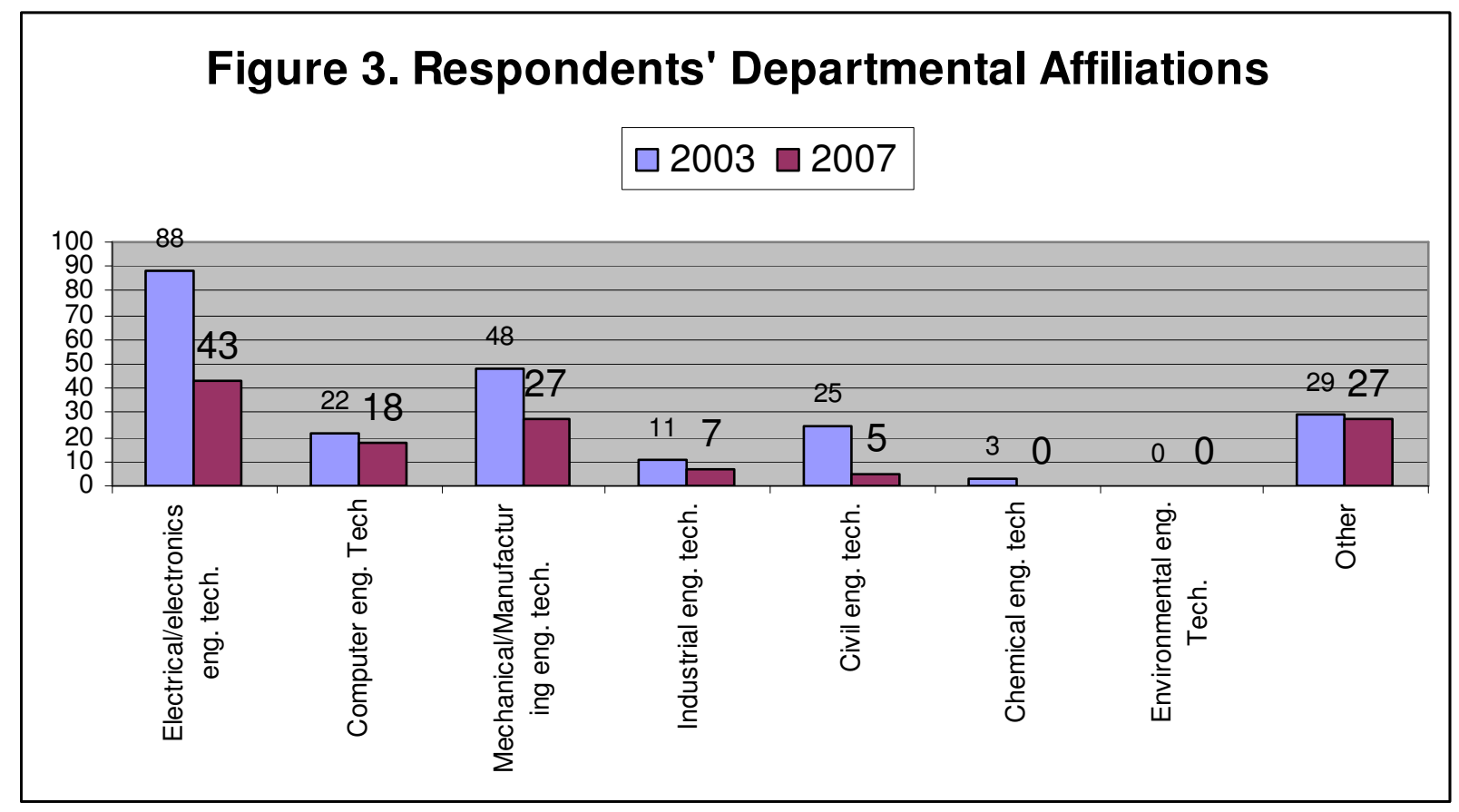

14. Respondents' Affiliation with TAC of ABET Accredited Programs: Figure 4 shows the frequency distribution of respondents' affiliations with TAC of ABET accredited programs.

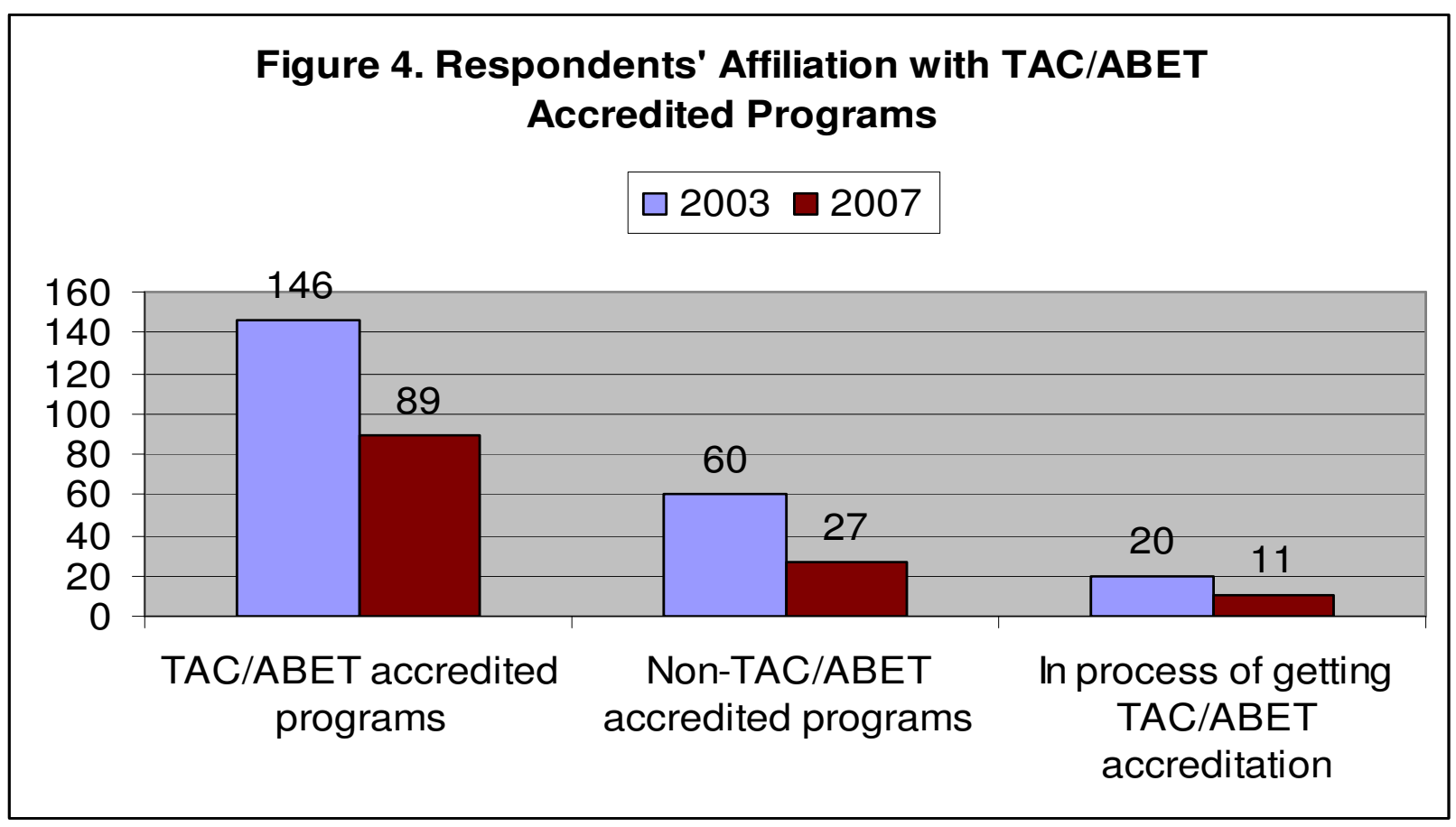


15. Respondents' Computer Competency/Information Technology (IT) hardware skills (PC \& Networking): Figure 5 illustrates the respondents' computer/IT/networking hardware skills. In 2007, twenty-two percent reported low-level skills, i.e. they have basic understanding of computer hardware/network systems (19\%, 2003); 45\% of respondents said that they have medium-level skills, i.e., they have understanding of computer/network systems $(54 \%, 2003)$; and $32 \%$ reported to have high-level skills, i.e., they can design hardware/network systems $(26.5 \%, 2003)$.

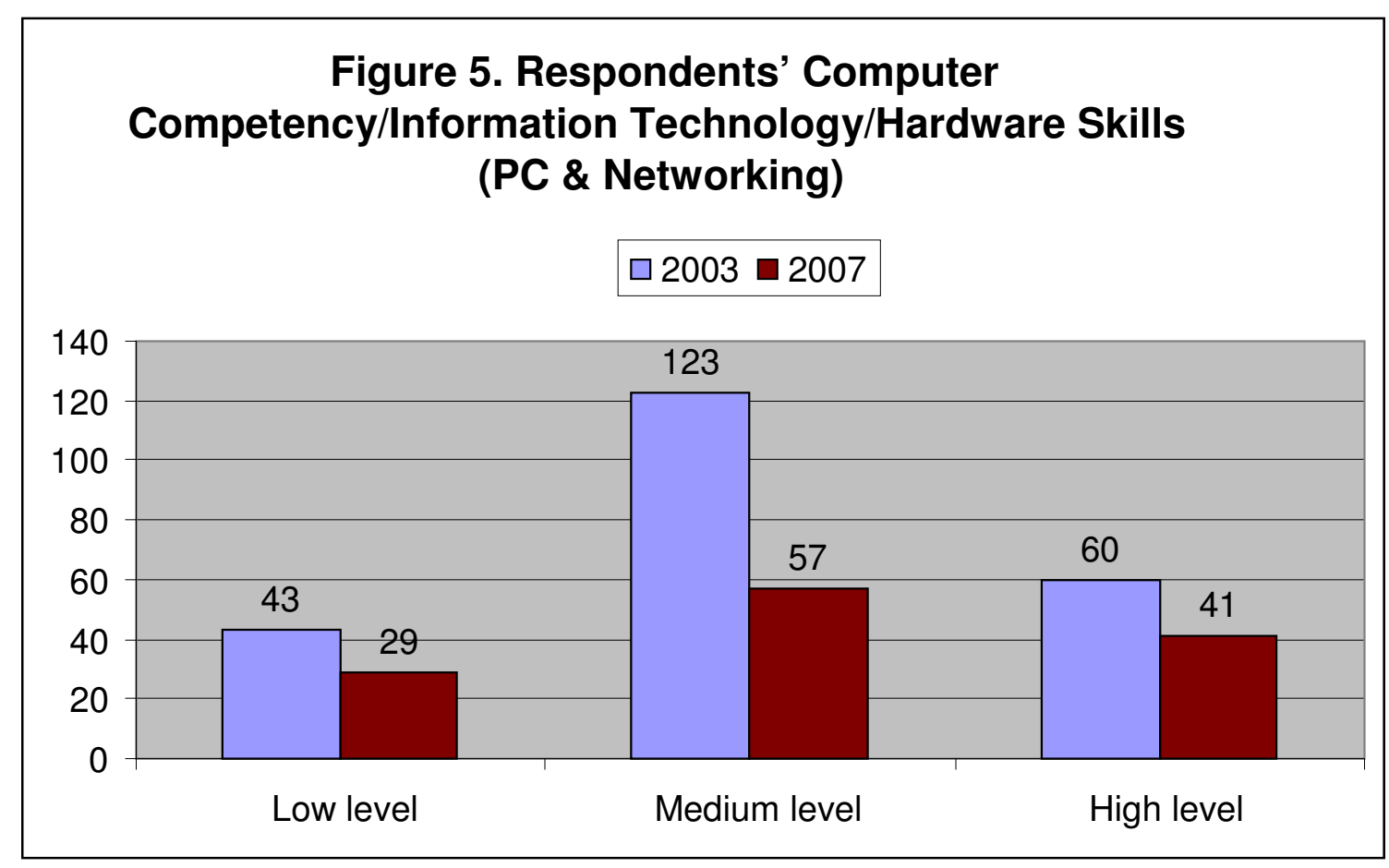

16. Computer Competency/Information Technology (IT) Software skills (PC \& Networking): Figure 6 illustrates respondents' computer competency/IT/networking software skills. In 2007, 23.6\% reporting low-level skills, i.e., they can use application software like MS-word, PowerPoint, Internet browsers, etc. (14\%, 2003); 55\% participants said that they have medium-level skills, i.e., they can write simple programs (49\%, 2003); and 32\% reported high-level skills, i.e., they are proficient in programming using high-level languages $(26.5 \%, 2003)$. 


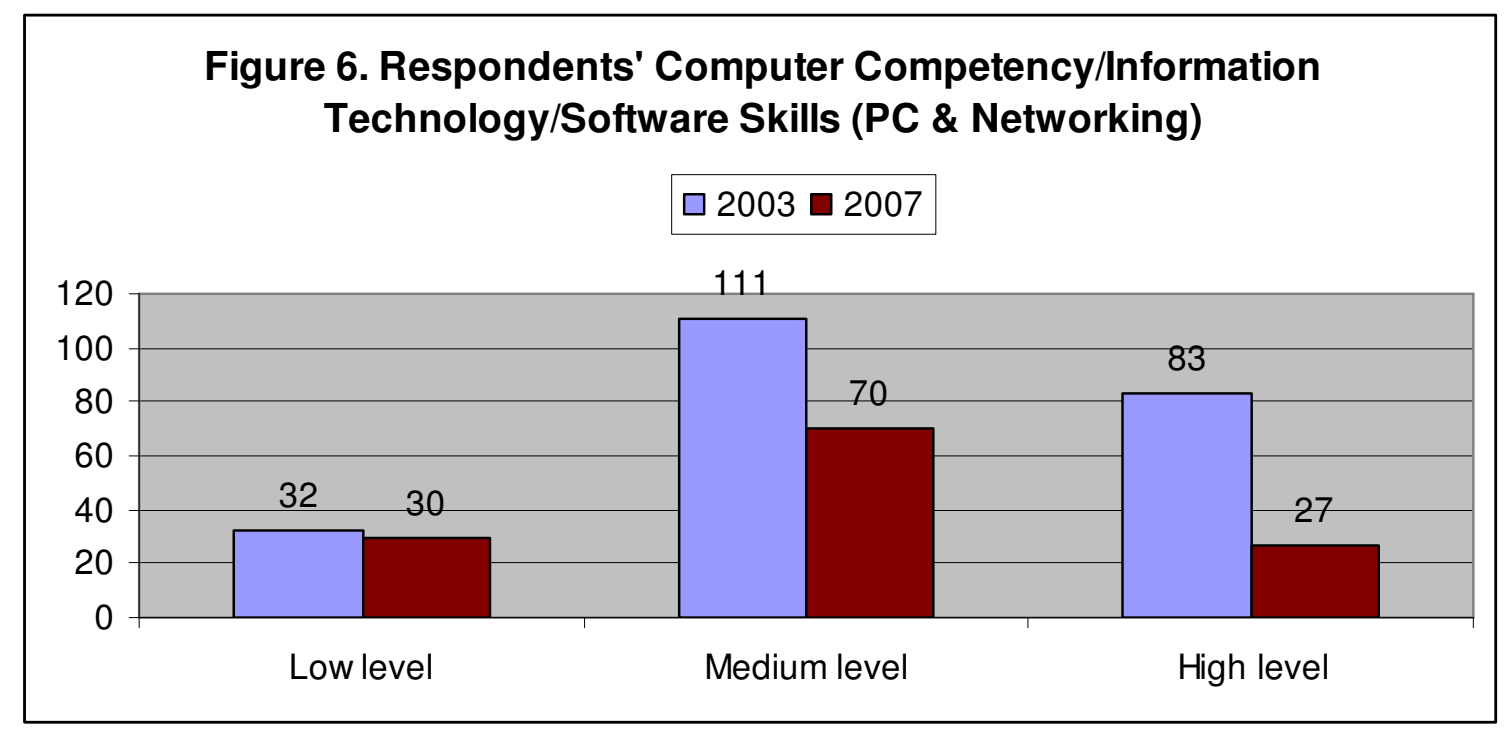

17. Department funds provided for professional development activities: Figure 7 shows the participants' reports of departmental funds for professional development on an annual basis; for $200716 \%$ participants reported that no funds were provided for professional development (17\%, 2003); $9 \%$ were provided $\$ 1$ - $\$ 200(20.4 \%, 2003)) ; 20 \%$ were given $\$ 201$ - \$ 500 (20\%, 2003); 22\% were provided $\$ 501$ - \$1000 (19\%, 2003); $15 \%$ were given $\$ 1001$ - $\$ 1500(19 \%, 2003)$; and $14 \%$ reported that they were granted more than $\$ 1500$ per year for professional development activities $(5 \%, 2003)$.

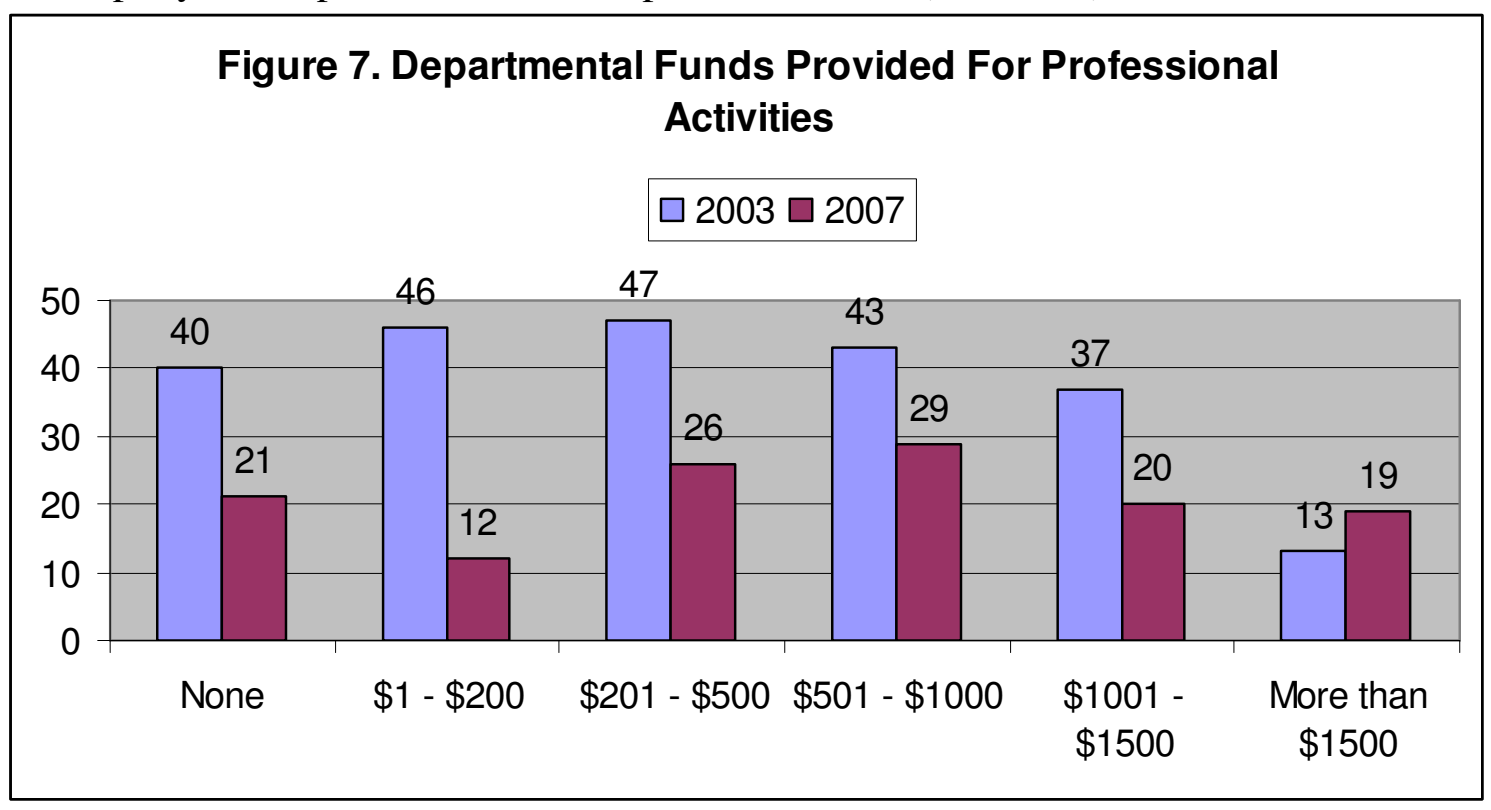

18. Personal Funds used for professional development activities: Figure 8 illustrates the participants' use of personal funds for professional development; for 2007, 13\% of participants reported that they did not use any personal funds $(18.1 \%, 2003) ; 33 \%$ spent $\$ 1$ - \$ 200 (27.4\%, 2003); $16.5 \%$ used \$201 - \$500 (20.8\%); 14\% paid \$501 - \$ 1000 
(19\%, 2003); $4.7 \%$ spent $\$ 1001$ - $\$ 1500$ (17\%); and $16.5 \%$ of participants said that they used more than $\$ 1500$ of personal funds for professional development $(7.1 \%, 2003)$.

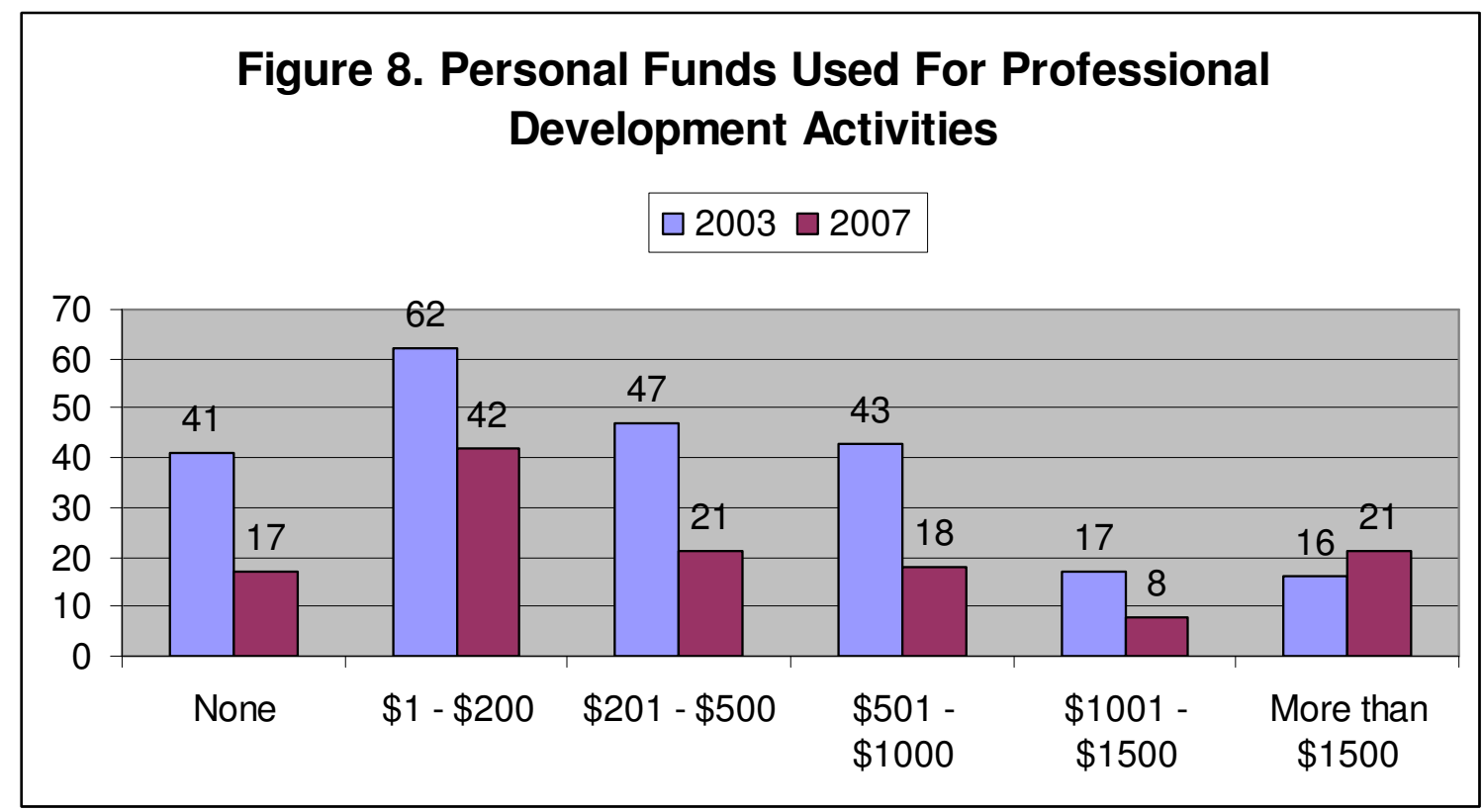

19. Teaching Experience: Survey participants' teaching experience is shown in Figure 9. Thirty-five percent of the participants have more than 20 years of teaching experience (31\%, 2003); 14\% have 16-20 years experience $(17.3 \%, 2003)$; $13 \%$ have $11-15$ years experience $(16.4 \%)$; $18 \%$ have $6-10$ years experience; $13 \%$ have $3-5$ years $(11.9 \%$, $2003)$; and $5 \%$ have $0-2$ years of teaching experience $(8.4 \%, 2003)$.

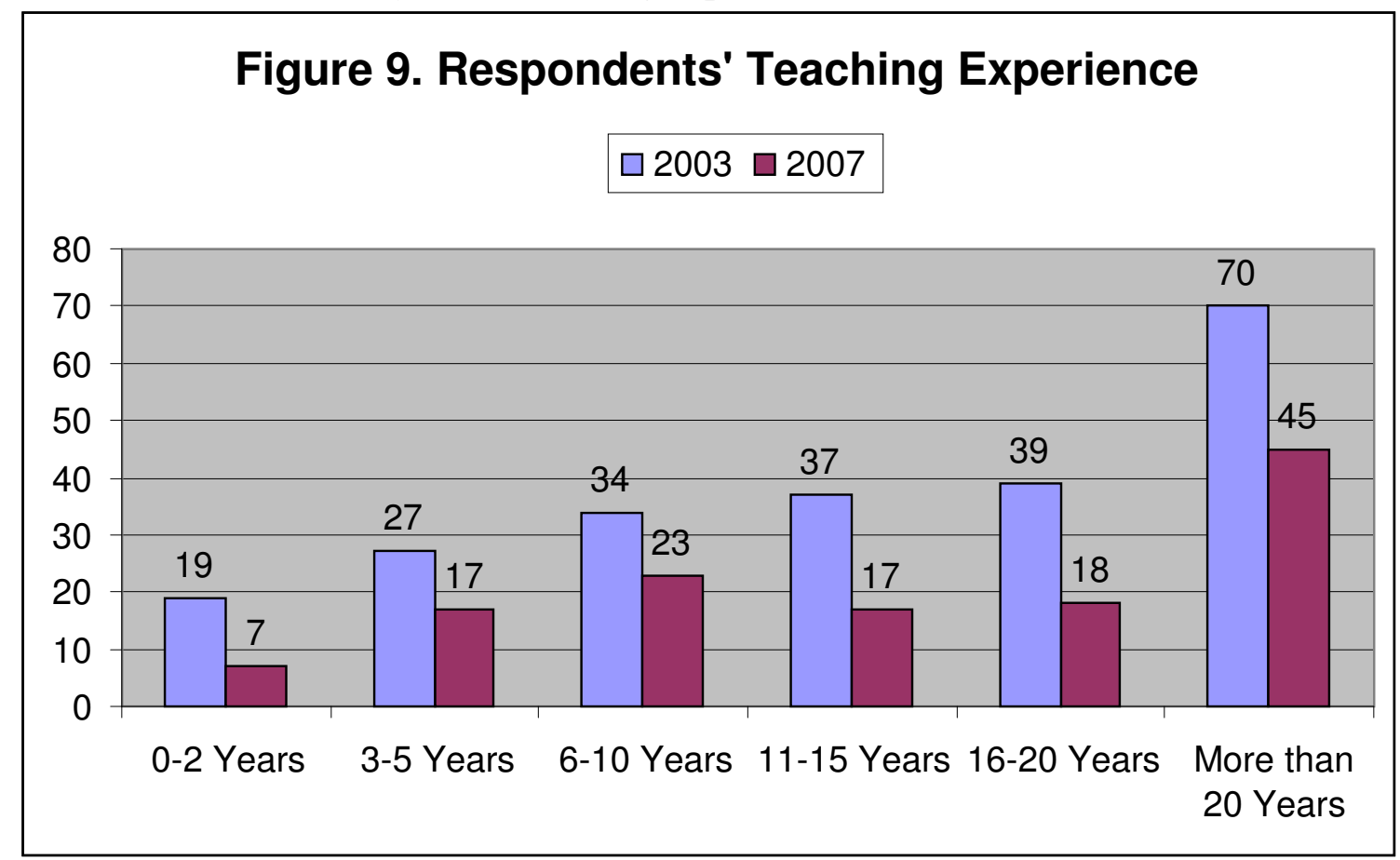


20. Recent Industrial/Consulting Experience: Forty percent of participants reported more than 5 years of industrial/consulting experience $(50 \%, 2005) ; 16 \%$ reported 2-4 years experience $(15.9 \%, 2003)$; $17 \%$ stated $1-2$ years experience $(18.6 \%, 2003)$; and $25 \%$ reported no recent industrial or consulting experience $(15.5 \%, 2003)$ [Figure 10].

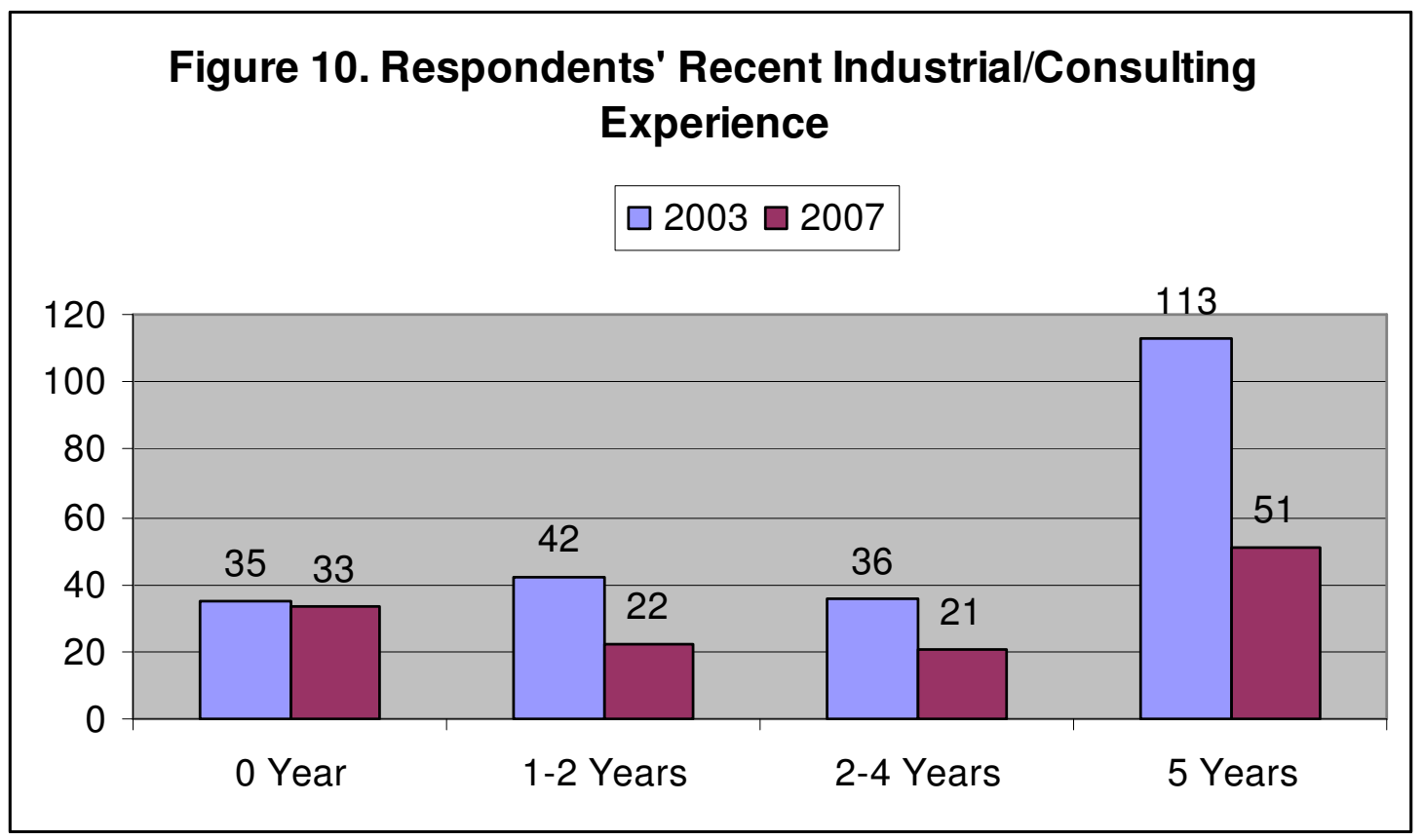

21. Highest educational degree completed: Figure 11 shows the highest degree completed by the survey participants; $32 \%$ have the Ph.D. or other doctorate $(34.1 \%$, $2003) ; 38 \%$ have a masters degree $(56.6 \%, 2003) ; 27 \%$ have a baccalaureate degree $(8.4 \%, 2003)$; and $1.6 \%$ reported that they have only industrial experience $(0.9 \%, 2003)$.

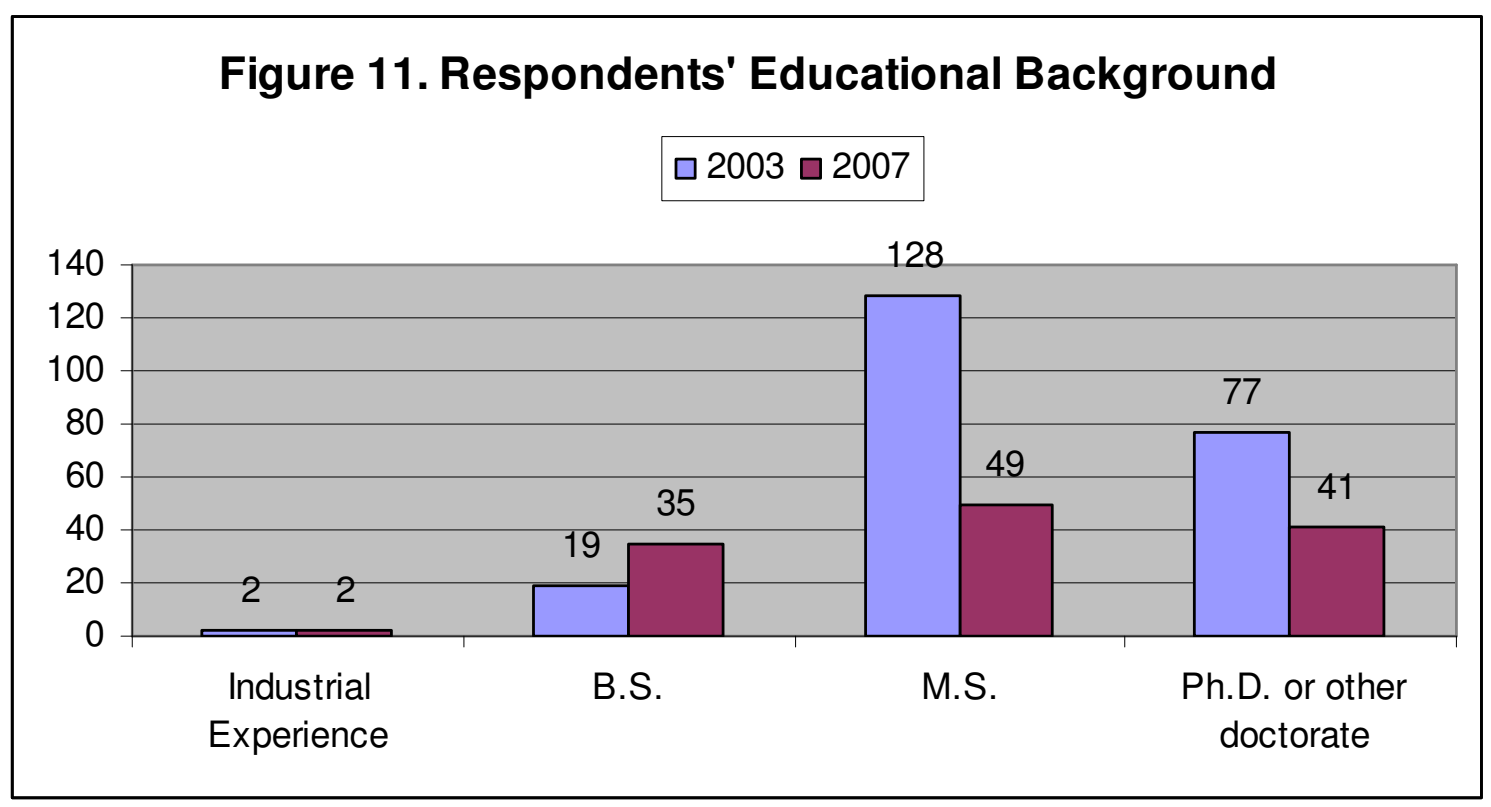


22. Institutional expectations for conducting research/publications: Sixty-five percent of respondents reported that they are not expected to conduct research and do publications $((71 \%, 2003)$; and $35 \%$ reported that they are required to do so $(29 \%, 2003)$.

23. Gender: Out of 127 respondents, 17.3 were females $(13.7 \%, 2003)$, and $82.7 \%$ were males $(86.3 \%, 2003)$.

24. Professional Membership: Figure 12 shows the respondents' professional society affiliations.

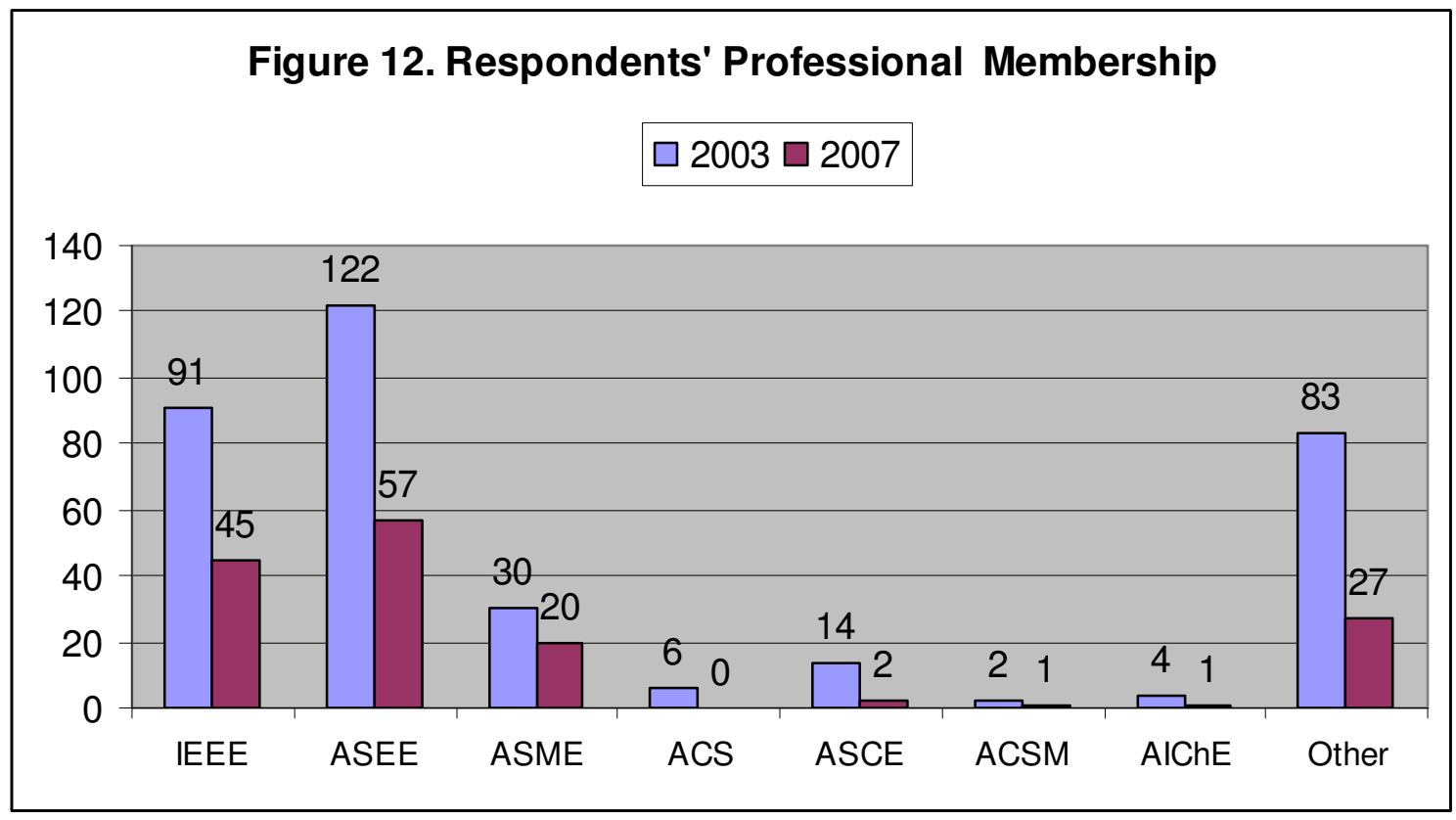

25. Training in Pedagogy of teaching and learning: Out of 127 participants, $46.6 \%$ reported that they did receive training in the pedagogy of teaching and learning $(52.7 \%$, $2003)$, and $53.5 \%$ said that they did not receive such training $(47.3 \%, 2003)$.

\section{Participants' Feedback/Comments regarding the importance of faculty technical} currency and faculty development on student learning/success: Out of 127 respondents, $29 \%$ also completed the comments section of the survey. The following is a sample of selected comments.

- "Maintaining technical currency is not only important, it is extremely important if we are expected to produce competent graduates who are prepared for entry level positions in industry."

- "Without any doubt, technical currency is the main reason students remain in school. They do not care to learn much about past history, they are fairly savvy about what is current, and they want to learn current topics and future topics. They are very focused. For example, if they take a programming course and it 
only uses console applications -- they know DOS is dead. They came to school to learn mainly current visual technology, not history."

- "Good survey. I'm glad I could be a part of this. As our nation continues to hang in the balance of preparing our students to compete in the global markets. Professors, instructors, and teachers need to stay apprised on the latest technological advancements. Whether educators like the word compete or not, that's what we are doing - competing. We are competing with international markets to sustain viability of employment for our current and future generations of students."

- "My personal efforts to maintain my engineering design and manufacturing company have provided a great incentive to stay current with the state-of-the-art. I pass what I know along to my students. They are willing learners when I can advise them with confidence born of first-hand experience. My school no longer stresses membership or participation in professional organizations."

- "I am teaching a first degree course in electronics. I believe the fundamentals have not changed as much as the advances that have been made in this field. I am trying my best to keep a balance between teaching the basic knowledge and the concepts that student can absorb and the current technology with its demands. There is hardly enough time to cover the fundamentals; must be careful not to turn the development into an overkill thereby cannibalizing the basics."

- "Some basic things never change, freshman courses, but as you get into the specific classes it is very important to know what the industry is doing and to keep current. One of the classes I teach is wireless communications and it changes with each class I teach. The books are never current so I have to research and stay current to keep the students current."

- "To teach is to learn twice with current state of the art, particularly in science and technology."

- "I usually request one course I've never taught before each semester to continuously extend my knowledge and expertise."

- "Surveys don't often have good participation because they are not as easy to complete as this one is. However, there appears to be missing information concerning why I mildly disagree with the statements. I am lead to a belief that not much could actually be made of these survey results."

- "It is good for us to network with professionals in companies that hire technicians."

- "In my opinion, it is an absolute necessity that technical educators spend time at conferences, workshops, seminars, working in industry, etc. It is very easy to lose touch with technology and industry trends and needs. Advisory Committees can play an important role in curriculum evaluation and development. Since 1998, a large percentage of my graduates have gone to work in "Clean room" environments. I had never been inside a clean room, until this past summer. I was able to spend a week in a clean room and build MEMS devices. Does this experience help me relate to my graduates and soon-to-be graduates? The answer is a resounding YES! I have first hand knowledge and experience and students know that I've been there, when I describe a clean room work environment. Helping students to understand industry, work environments, job 
descriptions, etc. will help them succeed. And the only way that an instructor can do these things is to stay in touch with the companies that are hiring the graduates."

- "Faculty technical currency is of the up most importance."

- "It is critically important. But I also think that in addition to financial support, faculty members need to be given time release and incentives so that they are encouraged to be pro-active in maintaining technical and academic currency. At the back end of this, insufficiently developed faculty will lead to reduced student learning and success and that will make our future graduates more incompetent and less competitive in the global marketplace."

- "Faculty technical currency is imperative to the quality of ET \& Industrial Technology Programs."

- "With regard to professional development and training, engineering faculty are in the same boat as medical and law professors are. Yet we get the same support as professors of sociology, English and arts."

- "Interesting survey. I wish all faculty, DeVry and all others, had your level of professional interest. I will look forward to seeing your published work. Hawaii is beyond my personal budget and prohibited by our leaders. Perhaps a question of who was funded for the 2007 ASEE Annual meeting, who primarily used personal funds. Another interesting thought is what is the percentage of attendees bringing a spouse to most ASEE annual meetings and what will it be for the 2007 Hawaii meeting."

- "Because there are so many damned workshops and conferences, we have to make too many choices. There need to be more regional or local workshops which develop in-depth hands-on and knowledge based, skill sets in a variety of technologies. We need a paradigm shift. The travel all over the place and modest learning that take place are an inefficient model."

- "I'm active in IEEE locally here in Phoenix, so I have volunteered to help at conferences, and so can attend free. It would be nice to figure out a way to encourage this! With the new MS program in progress, it's going to be more important for us to have a presence at conferences."

- "Engineering Technology is the practice of engineering. It is essential that all faculty in E.T. have practical experience, and that they remain current with industry."

- "Certainly the best way of teaching the subject is to completely know the subject matter and the best way of knowing the subject is doing the subject and a close second is to at least know about the latest technologies pertaining to your discipline. At the very least the Instructor must be prepared to research any topic(s) that is questioned by the student in the classroom and not just "pass over" the question as if it's not important. The instructor may look somewhat embarrassed if he/she doesn't know the answer immediately BUT this should not stop the instructor from finding the answer and returning to the classroom with a positive attitude that he/she and the students have now learned something and that both constituents are the better for it! 
- "Look at the lag from new product idea to course idea to textbook - it's a "lifetime" in terms of computer/network applications. Concepts have come and gone before we integrate them into the curriculum. We look out-of-date to the students, because we are."

- "Technical currency, while important is not as important as utilizing current teaching pedagogy."

- "Faculty development is critical in engineering education."

- "Don't wait for the opportunity, take the bull by the horns and lead. Too may "followers" are waiting for the other guy to learn, then present technological advances or waiting for the "University" to pay them to take additional classes or attend seminars. Waiting is the best way to become obsolete. When faculty are engaging as life long learners, our students will see the importance of maintaining technological currency."

- "I strongly believe that faculty should teach in professional engineering educational programs, pursue summer internships with industry to stay current and work with companies on joint projects with graduate students. I currently manage professional education programs in the College of Technology."

- "It should be taken seriously in promoting student learning/learning success."

- "It has to be funded AND supported with release time, travel funds and other resources. Time is the MOST critical of these; we can all scrape together the money if need be, but when you are teaching full sections, overload semesters and on-line courses who has the time to spare?"

- "Faculty currency with industry is a major portion of program failures, student retention, and student recruitment. Why I say this is that if a faculty is engaged in maintaining their industry currency this information will become part of the coursework they are teaching. This then leads to improvements in course materials and labs activities, which will improve student perceptions that this college is up to date and I am learning what is needed by the electronics industry or other technology industries. Ultimately this will improve student recruitment as potential students will see informed faculty and students eager to be in class and participating in labs, which could lead to the potential student registering for your programs. Trickle up or trickle down faculty development with industry is key to successful programs."

- "The faculty technical competence is essential in teaching successfully different classes. It's a basic rule of progress: everything moves forward: life, skills, transferring your skills to students, etc."

- "Technology progresses so fast that the aforementioned items have become a 'must' and our Educational Institutions should conform accordingly and without a delay. Thank you, good luck regarding your research and please keep us informed about your overall results."

- "Faculty should be self motivated. Do not expect others to pay for it. It is your profession."

- "NEED MORE PROFESSIONAL DEVELOPMENT FOR NEW FACULTY (MENTORING)."

- "It is one of about four keys to success. Others include industry involvement, lab content, and student quality of preparation." 
- "Technical currency is not by itself a significant determining factor. It helps relating subject matter to today, but student learning is dependent on the key classical factors: Classroom management, delivery, classroom interaction, and of course the student sensitivity and positive personal impact of the instructor."

- "Our university and department provide all resources for professional development."

- "Up keeping the technical currency of faculty is very important as new technologies emerge."

Appendix B lists the participants' comments for the 2003 survey.

\section{Implications for Practice/Recommendations}

Based on the survey results and participants' feedback, and comments, the following recommendations are made for maintaining and enhancing faculty technical currency and faculty development activities in order to improve the quality of instruction in engineering technology programs.

1. Administrators/chairpersons need to realize the importance of technical currency and its relationship to student learning/success.

2. Policies at institutional and departmental level needs to be revised in order to encourage faculty members to maintain their technical currency by planning and pursuing professional development activities.

3. Administrators/chairpersons need to synchronize the curriculum development and revision cycle with the planning and implementation of faculty development activities.

4. Institutions need to allocate appropriate funds for faculty developmental activities.

5. Institutions need to collaborate with industry for creating professional development activities for faculty. Faculty development grants could be solicited from industry, and opportunities for short/long term industrial sabbaticals for faculty should also be identified.

6. Institutions also need to realize the importance of the IT/computer competency in promoting student learning. All faculty members should be provided training opportunities to enhance their computer/IT/networking/hardware/software skills.

7. Faculty should be encouraged to pursue industrial experience via mini industrial sabbaticals and consulting work.

8. Administrators/chairpersons need to realize importance of the pedagogy in teaching and learning. And they should provide training opportunities for faculty to strengthen pedagogy in order to improve student learning/success. 


\section{Conclusion}

This paper highlights the importance of faculty technical currency. The faculty technical currency survey findings suggest that the majority of the participants believe that:

1. Because of the application orientation of engineering technology programs, technical currency of faculty is essential to make student learning more relevant (level of agreement: 2007 [97.8\%], 2003 [96.2\%]).

2. There is a strong relationship between faculty technical currency and student learning (level of agreement: 2007 [90.6\%], 88\% [2003]).

3. There is a need to revise institutional/developmental polices in order to encourage faculty to maintain technical currency (level of agreement: 2007 [59.2\%], 2003 [58.4\%].

4. There is a need to for the allocation of appropriate funds for professional development activities for faculty.

The rapid growth in technological domains has put new demands on the faculty in the engineering technology programs. In order to narrow the gap between the state-ofcurricula and the state-of- technology in the industry, faculty are required to revise curricula frequently, and maintain their technical currency. And to improve student learning/success, they need to enhance their pedagogical skills. This is very challenging, and requires institutional vision, planning, and allocation of appropriate resources.

\section{References}

1. Criteria for Accrediting Engineering Technology Programs (2006-2007), Criterion 5. Faculty, p. 7, available online at: http://www.abet.org

2. Boyer, Ernest. (1990). Scholarship Revisited: Priorities of the Professoriate. Carnegie Foundation for the Advancement of Teaching. Princeton, N.J.

3. Tapscott, D. (1996). The digital economy: Promise and peril in the age of networked intelligence. New York: McGraw-Hill.

4. Elbe, K.E., and McKeachie, W.J. (1985). Improving undergraduate education through faculty development: An analysis of effective programs and practices. San Francisco: Jossey-Bass.

5. Diamond, R.M. (2002). Faculty, instructional, and organizational development: Options and choices. In K.H. Gillespie (Ed.), A Guide to Faculty Development: Practical Advice, Examples, and Resources.(p. 3) Boston: Anker Publishing Company.

6. Khan, Ahmed., Karim, A., Gloeckner, G., \& Morgan, George. (2004). Faculty Technical Currency: Status Report on a National Survey of Engineering Technology Faculty. Presented at 2004 ASEE Annual Conference, Salt lake City, UT, June 20-23, 2004. 


\section{Appendix A}

\section{Dear Colleague:}

As you know the declining student enrollments and shrinking funds for professional development have imposed new challenges for technology faculty who wish to pursue professional development activities to maintain technical currency. We believe that faculty professional development activities and technical currency play an important role in promoting student learning and student retention. In this regard, we would like to explore the state of faculty technical currency and scholarship. Therefore we invite you to participate in our survey project. To ensure your confidentiality, you are not required to write your name on the attached survey questionnaire. Your participation in this project is strictly voluntary, and information gathered for this study will remain confidential. Answering the questionnaire will not take more than 10 minutes. You can complete this survey online by clicking on the following URL:

http://www.dpg.devry.edu/ khan/FTCSurvey/

We plan to present the results of this survey at the 2007 ASEE conference. We will also compare the results with the survey conducted earlier in 2004. We hope that the results of this study will help to improve the quality of instruction in engineering technology programs and lead to enhancing faculty development activities and scholarship.

Thank you for your willingness to participate in this research study.

Sincerely

Ahmed S. Khan, Ph.D.

Professor, EET Dept.

DeVry University, Addison, IL 60101

Amin Karim

Director, Technology Programs

DeVry University, Corporate Academic Affairs

Addison, IL 60101 


\section{Faculty Survey on Technical Currency}

For Questions 1-10, please use the following scale.

$1=\mathrm{I}$ strongly disagree with this statement (SD)

$2=\mathrm{I}$ disagree with this statement $(\mathrm{D})$

$3=\mathrm{I}$ moderately disagree with this statement (MD)

$4=\mathrm{I}$ neither agree nor disagree with this statement $(\mathrm{N})$

$5=$ I moderately agree with this statement (MA)

$6=\mathrm{I}$ agree with this statement (A)

$7=\mathrm{I}$ strongly agree with this statement (SA)

Please circle the appropriate number.

\begin{tabular}{|c|c|c|c|c|c|c|c|}
\hline & SD & $\mathrm{D}$ & MD & $\mathrm{N}$ & MA & $\mathrm{A}$ & SA \\
\hline $\begin{array}{l}\text { 1. Because of the application orientation of engineering } \\
\text { technology programs, technical currency of faculty is essential to } \\
\text { make student learning more relevant. }\end{array}$ & 1 & 2 & 3 & 4 & 5 & 6 & 7 \\
\hline $\begin{array}{l}\text { 2. I believe that there is a strong relationship between the } \\
\text { technical currency of the faculty member and student } \\
\text { learning/success. }\end{array}$ & 1 & 2 & 3 & 4 & 5 & 6 & 7 \\
\hline $\begin{array}{l}\text { 3. My institution supports and encourages faculty members to } \\
\text { maintain technical currency. }\end{array}$ & 1 & 2 & 3 & 4 & 5 & 6 & 7 \\
\hline $\begin{array}{l}\text { 4. My chairperson supports and helps me plan professional } \\
\text { development activities to maintain technical currency. }\end{array}$ & 1 & 2 & 3 & 4 & 5 & 6 & 7 \\
\hline $\begin{array}{l}\text { 5. I believe that I have maintained technical currency during the } \\
\text { past } 5 \text { years, enabling me to teach courses effectively. }\end{array}$ & 1 & 2 & 3 & 4 & 5 & 6 & 7 \\
\hline $\begin{array}{l}\text { 6. My institution has allocated sufficient funds for the } \\
\text { professional development activities of faculty during the past } 5 \\
\text { years. }\end{array}$ & 1 & 2 & 3 & 4 & 5 & 6 & 7 \\
\hline $\begin{array}{l}\text { 7. There is an urgent need in my department/program to improve } \\
\text { existing policies in order to allow faculty to enhance their } \\
\text { technical currency. }\end{array}$ & 1 & 2 & 3 & 4 & 5 & 6 & 7 \\
\hline $\begin{array}{l}\text { 8. There is an urgent need in my department/program to increase } \\
\text { funding for faculty development activities. }\end{array}$ & 1 & 2 & 3 & 4 & 5 & 6 & 7 \\
\hline $\begin{array}{l}\text { 9. ABET's new TC2K accreditation criteria will encourage my } \\
\text { institution to revise policies in order to promote faculty } \\
\text { development activities in order to keep faculty technically current. }\end{array}$ & 1 & 2 & 3 & 4 & 5 & 6 & 7 \\
\hline $\begin{array}{l}\text { 10. ABET's new TC } 2 \mathrm{~K} \text { accreditation criteria will encourage my } \\
\text { institution to allocate adequate financial resources for faculty } \\
\text { development activities. }\end{array}$ & 1 & 2 & 3 & 4 & 5 & 6 & 7 \\
\hline
\end{tabular}

11. How do you stay current (or maintain technical currency) with the pace of technological change? (Check all that apply)

$\square$ Active participation in professional organizations

$\square$ Presenting papers at conferences/writing papers in peer-reviewed publications

$\square$ Attending conferences/technical workshops/seminars

$\square$ Reading books, technical magazines, and trade journals

$\square$ Keeping up-to-date via the Internet

$\square$ Knowledge/skill transfer from senior faculty/colleagues

$\square$ Working as a consultant in industry 


\begin{tabular}{|c|c|}
\hline 12. I am affiliated $\mathrm{w}$ & $\begin{array}{l}\text { a: } \\
\text { State supported 4-year university } \\
\text { State supported 2-year program/community college } \\
\text { Private non-profit 4-year university } \\
\text { Private for profit 4-year university }\end{array}$ \\
\hline 13. My departmenta & $\begin{array}{l}\text { ffiliation: } \\
\square \text { Electrical and electronics engineering technology } \\
\square \text { Computer engineering technology } \\
\square \text { Mechanical/Manufacturing engineering technology } \\
\square \text { Industrial engineering technology } \\
\square \text { Civil engineering technology } \\
\square \text { Chemical engineering technology } \\
\square \text { Environmental engineering technology } \\
\square \text { Other }\end{array}$ \\
\hline 14. Do you teach in & $\begin{array}{l}\text { TAC of ABET accredited program? } \\
\text { Yes } \\
\text { No } \\
\text { We are in process of getting the accreditation }\end{array}$ \\
\hline $\begin{array}{r}\text { 15. Indicate your co } \\
\square \mathrm{Lo} \\
\square \mathrm{Me} \\
\square \mathrm{Hig}\end{array}$ & $\begin{array}{l}\text { puter competency/Information Technology (IT) hardware skills (PC \& Networks): } \\
\text { evel (Basic understanding of computer hardware/network systems) } \\
\text { um level (have understanding of computer/network systems) } \\
\text { level (can design hardware/network systems) }\end{array}$ \\
\hline $\begin{array}{r}\text { 16. Indicate your co } \\
\square \text { Loy } \\
\text { bro } \\
\square \mathrm{Mec} \\
\square \mathrm{Hig}\end{array}$ & $\begin{array}{l}\text { puter competency/Information Technology (IT) software skills (PC \& Networks): } \\
\text { evel (can use application software word, PowerPoint, Internet } \\
\text { ers, etc) } \\
\text { Im level (can write simple programs) } \\
\text { evel (proficient in programming using high-level languages) }\end{array}$ \\
\hline $\begin{array}{l}\text { 17. Indicate the amo } \\
\text { development activiti }\end{array}$ & $\begin{array}{l}\text { t of departmental funds provided to you annually for participation in professional } \\
\text { (conferences, workshops, seminars, etc). }\end{array}$ \\
\hline $\begin{array}{l}\square \text { None } \\
\square \$ 1-\$ 200 \\
\square \$ 201-\$ 500 \\
\square \$ 501-\$ 1000 \\
\square \$ 1001-\$ 1500 \\
\square \text { More than } \$ 1500\end{array}$ & \\
\hline $\begin{array}{l}\text { 18. Indicate the amo } \\
\text { development activiti }\end{array}$ & $\begin{array}{l}\text { of personal funds you spent over the last year for participation in professional } \\
\text { conferences, workshops, seminars, etc). }\end{array}$ \\
\hline $\begin{array}{l}\square \text { None } \\
\square \$ 1-\$ 200 \\
\square \$ 201-\$ 500 \\
\square \$ 501-\$ 1000 \\
\square \$ 1001-\$ 1500 \\
\square \text { More than } \$ 1500\end{array}$ & \\
\hline
\end{tabular}




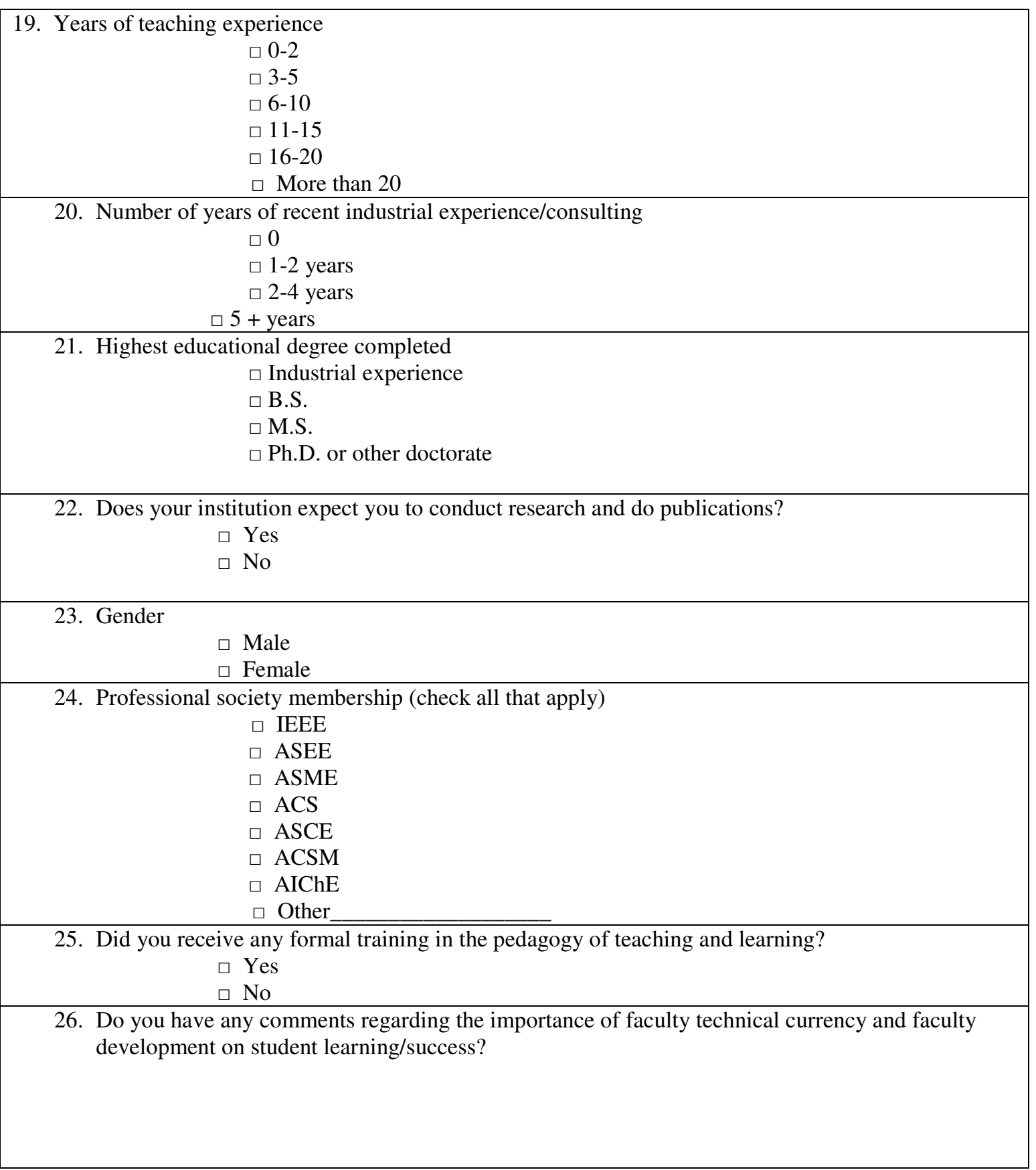




\section{Appendix B \\ (Response to Q; 26 for 2003 Survey)}

\section{Participants Feedback/Comments regarding the importance of faculty technical}

currency and faculty development on student learning/success: Out of 226 respondents, $24 \%$ also completed the comments section of the survey. The following is a sample of selected comments.

- "This is a highly important topic that receives extremely little attention."

- "Administrators ought to realize the importance of technical currency and professional development of faculty. And in this regard they need to plan appropriate faculty development activities and allocate required funds."

- "I believe it is extremely important. I would also suggest that currency can be attained or maintained through faculty internships (summers) and industry-based sabbaticals."

- "Instructors should be encouraged to take one course of their choice per year leading to specialization into a new field so that they can expand their field of teaching. They should be given the opportunity to teach a course in the new field."

- "Faculty technical currency is absolutely critical to student learning/success. I have been teaching for 38 years and I maintain that I have not taught the same course twice because each course is updated and upgraded reach term. Technology is changing too fast for faculty members to become complacent."

- "Technical Currency without ability to teach that competency to students is worthless."

- "I believe there is a strong relationship between work experience and student learning. If the faculty can relate the material at hand to what is going on in the work place today the student is more likely to take it seriously."

- "Close connections to local and regional large companies... would be very useful in terms of transferring technologies, and resources into teaching institutions."

- "As faculty we really have two areas in need of currency both in our technical specialty and also in teaching. Often faculty, especially tenure track, concentrate too much on the tech. Research instead of learning to be better teachers. There is a lot of technology to teaching these days and it is a disservice to our students to not be current in teaching as well as research."

- "Technical competency is important for ET faculty, but a knowledge and understanding of cognitive science and research is equally important. Too many faculty think that it is easy and simple to teach, but the human mind is the most complex system we will ever deal with!"

- "The most frequent requirement that we face is to learn all the new feature of an upgrade of current software, but we are expected to learn this on our own."

- "Department heads/chairs should realize the importance of technical currency issues via faculty development activities!"

- "Technical currency for my faculty is not funded through institutional resources. Rather, we have developed an industry endowment that takes care of our 
development needs. Try it; it will really make you independent from politicians and university administrators."

- "We do not have fixed budgets for training or equipment. We can make requests and they may or may not be approved based on need and available funds."

- "The degree of technical currency required is function of the student's technical awareness and ability. Many of the students and most in some schools are woefully lacking in math skills and scientific reasoning. They come from a background where learning is not valued and in some case devalued. The ability to teach such that the students learn the basics of ET is more important than being up on the latest technology."

- "Every faculty member should be encouraged to complete several classes from the education department to assist in the development of teaching skills. The skill of teaching young men and women is not automatically obtained..."

- "I take full responsibility for my own development. I use primarily self-study and working with industry to keep myself current."

- "We need easy and rapid dissemination of best practices as found by educational research centers."

- "Why educate our students to a standard that is ten years old? ...Wouldn't it be better to educate our students for the standard that will exist ten years in the future? How can this be done without technical currency?"

- "Technical currency is important but not critical. In-depth awareness is much more important as we work to establish a firm intellectual foundation upon which our young people may build their intellect and skills... If we prepare a wellrounded engineer with excellent scholastic skills they themselves will seek out those technical advancements we were unable to share with them. A welldeveloped mind is an inquisitive mind so why not develop the mind placing emphasis on what one needs to know."

- "Resources are the key, you can have all the policies and good intentions you want but if they aren't backed by resources it won't happen!"

- "Technical currency is one of the utmost importance. My community college permits all of the electronics faculty members to serve as consultants..."

- "Community college funding needs to be on par with universities and public school systems in order for faculty to stay technically current."

- "I would not limit application of specific technical competence to technology faculty only. All engineering and related faculty should be required to operate with real world experience of survival beyond academia."

- "The faculty MUST be willing to take every opportunity to increase in skills, especially in areas that are unfamiliar to the individual faculty member. We have seen a direct benefit to student learning and success when the faculty members are given professional development time and use it."

- "Technology is so rapidly changing that it is difficult to keep up but doing so is a necessity. Guess we just have to bite the bullet because this is what we love."

- "No one at this college realizes they are teaching technology that is at least 20-25 years old." 
- "My dean once said that since we teach a 4/4 load without grad students and have no lab or reasonable library facilities, he does not expect us to do research. As long as we produce a couple of publications each year, he will be happy!"

- "Faculty technical currency, in itself, does not insure student learning/success. However, technical currency combined with good teaching skills will insure the highest probability that student learning/success will take place."

- "Professional development, in my case, has been a personal decision. Sure, professional development is promoted in the faculty agreement with management, but lack of institutional funds is a drawback. Even when external funding is available, administration will not grant release-time, desiring instead to have faculty remain in the classroom (the mentality that a teacher's place is in the classroom, not participating in professional development activities). Community college administrators are not very wise when it comes to professional development of full-time and part-time faculty. Like managers in industry, they are interested in short-term, not long term, results."

- "Applied research is an important part of the total package of teaching and learning technology. Faculty in technology positions must stay current with the changes in technology, the fundamentals that support the technology and the changing techniques and pedagogy of technical teaching. The challenges are real. Faculty and the administrations they work for need to do more to recognize this need and put specific plans in place to keep academic programs growing and strong."

- "Faculty technical currency and faculty development are absolutely essential for student learning."

- "Stay current or drag your students slowly down."

- "Faculty technical currency is essential to improvement of the education process."

- "Technical currency is vital, both as a practicing engineer and as an engineering educator. I spend a fourth to third of my time trying to keep current."

- "Faculty technical currency is very important but I would rate faculty development and training in pedagogy a little higher in terms of importance to our ET program."

- "It is very important because industrial applications are constantly changing, and there is a vast overlap of technologies. Also, students need to know of emerging technologies in electronics, computer, and software, mechanical and manufacturing fields."

- "University, industry, and community are in it together. It is very important to have a process/mechanism to retool/upgrade technical currency of faculty. Otherwise the system will be functioning at its minimum and ultimately producing mediocre workforce with numbers." 